\title{
PURIFICATION AND N-TERMINAL SEQUENCING OF TWO PRESYNAPTIC NEUROTOXIC PLA 2 , NEUWIEDITOXIN-I AND NEUWIEDITOXIN-II, FROM Bothrops neuwiedi pauloensis (JARARACA PINTADA) VENOM
}

BORJA-OLIVEIRA C. R. (1), KASSAB B. H. (2), SOARES A. M. (3), TOYAMA M. H. (2), GIGLIO J. R. (4), MARANGONI S. (2), RE L. (5), RODRIGUES-SIMIONI L. (1)

(1) Department of Pharmacology, School of Medical Sciences, State University of Campinas, UNICAMP, Campinas, São Paulo State, Brazil; (2) Department of Biochemistry, Institute of Biology, State University of Campinas, UNICAMP, Campinas, São Paulo State, Brazil; (3) Department of Clinical, Toxicological and Bromatological Analyses, School of Pharmaceutical Sciences, FCFRP, University of São Paulo, USP, Ribeirão Preto, São Paulo State, Brazil; (4) Department of Biochemistry and Immunology, School of Medicine, University of São Paulo, USP, Ribeirão Preto, São Paulo State, Brazil; (5) Institute of Experimental and Clinical Sciences, Laboratory of Pharmacology, University of Ancona, Ancona, Italy.

ABSTRACT: Two presynaptic phospholipases $A_{2}\left(P L A_{2}\right)$, neuwieditoxin-I (NeuTX-I) and neuwieditoxin-II (NeuTX-II), were isolated from the venom of Bothrops neuwiedi pauloensis (BNP). The venom was fractionated using molecular exclusion HPLC (Protein-Pak 300SW column), followed by reverse phase HPLC ( $\mu$ Bondapak $\mathrm{C} 18$ column). Tricine-SDS-PAGE in the presence or absence of dithiothreitol showed that NeuTX-I and NeuTX-II had a molecular mass of approximately $14 \mathrm{kDa}$ and $28 \mathrm{kDa}$, respectively. At $10 \mu \mathrm{g} / \mathrm{ml}$, both toxins produced complete neuromuscular blockade in indirectly stimulated chick biventer cervicis isolated preparation without inhibiting the response to acetylcholine, but NeuTX-II reduced the response to $\mathrm{KCl}$ by $67.0 \pm 8.0 \% \quad(\mathrm{n}=3 ; p<0.05)$. NeuTX-I and NeuTX-II are probably responsible for the presynaptic neurotoxicity of BNP venom in vitro. In fact, using loose patch clamp technique for mouse phrenic nerve-diaphragm preparation, NeuTX-I produced a calcium-dependent blockade of acetylcholine release and caused appearance of giant miniature end-plate potentials (mepps), indicating a pure presynaptic action. The N-terminal sequence of NeuTX-I was DLVQFGQMILKVAGRSLPKSYGAYGCYCGWGGRGK (71\% homology with bothropstoxin-II and $54 \%$ homology with caudoxin) and that of NeuTX-II was SLFEFAKMILEETKRLPFPYYGAYGCYCGWGGQGQPKDAT (92\% homology with Basp-III and $62 \%$ homology with crotoxin PLA2). The fact that NeuTX-I has Q-4 (GIn-4) and both toxins have F-5 (Phe-5) and Y-28 (Tyr-28) strongly suggests that NeuTX-I and NeuTX-II are Asp49 PLA 2 .

KEY WORDS: chick biventer cervicis, loose patch clamp, nerve-muscle preparation, neuromuscular junction, neurotoxicity, $\mathrm{PLA}_{2}$ neurotoxin, presynaptic action, Bothrops neuwiedi pauloensis, Neuwieditoxin-I, Neuwieditoxin-II.

CONFLICTS OF INTEREST: There is no conflict.

\section{CORRESPONDENCE TO:}

LÉA RODRIGUES-SIMIONI, Departamento de Farmacologia, Faculdade de Ciências Médicas, Universidade Estadual de Campinas (UNICAMP), Caixa Postal 6111, 13083-970, Campinas, SP, Brasil. Phone: 55-19-3788-9534; Fax: 55-19-3289-2968.

Email: simioni@unicamp.br. 
C. R. Borja-Oliveira et al. PURIFICATION AND N-TERMINAL SEQUENCING OF TWO PRESYNAPTIC NEUROTOXIC PLA2, NEUWIEDITOXIN-I AND NEUWIEDITOXIN-II, FROM Bothrops neuwied pauloensis (JARARACA PINTADA) VENOM. J. Venom. Anim. Toxins incl. Trop. Dis., 2007, 13, 1, p. 104

\section{INTRODUCTION}

Out of the four genera of venomous snakes in Brazil (Bothrops, Crotalus, Lachesis and Micrurus), only Crotalus and Micrurus cause failure of the neuromuscular junction, producing peripheral muscular weakness. However, the main complications in lethal envenomations by Bothrops species are acute renal failure, shock and sepsis $(6,41)$. Respiratory failure is also observed sometimes but the mechanism is not well understood. Since Bothrops venoms produce no signs of neurotoxicity after snakebite, respiratory failure has been related to pulmonary edema (41).

The neuromuscular actions of various Bothrops venoms have been extensively investigated in recent years. Cogo et al. (9) reported the neurotoxicity of Bothrops insularis venom on mice and chicks and on mouse phrenic nerve-diaphragm (MPND) and chick biventer cervicis (CBC) isolated preparations. After a lethal intramuscular (i.m.) dose of venom, chicks showed flaccidity followed by head-drop, dyspnea, apnea, convulsions and death. The venom produced irreversible blockade of MPND and $\mathrm{CBC}$, and increased the frequency of mepps in mouse diaphragm. Subsequently, a neurotoxic presynaptic $\mathrm{PLA}_{2}$ fraction, which blocked indirectlyevoked twitches in $\mathrm{CBC}$ but did not affect the responses to acetylcholine (ACh) and $\mathrm{KCl}$, was isolated from this venom (10).

Zamuner et al. (53) reported that $B$. neuwiedi venom caused head-drop, loss of balance and respiratory failure in chicks, after an i.m. dose of $0.55 \mathrm{mg} / \mathrm{kg}$. The venom also inhibited the twitch-tension responses in CBC preparations, but did not decrease the contractures to exogenous $\mathrm{ACh}$ or $\mathrm{KCl}$, thus suggesting a presynaptic action. Borja-Oliveira et al. (5) subsequently investigated the neurotoxicity of several lots of $B$. neuwiedi venoms on $\mathrm{CBC}$ and observed that not all $B$. neuwiedi venoms exhibited neurotoxicity. Furthermore, analysis of the neurotoxic action of a sample of $B$. neuwiedi pauloensis (BNP) venom on CBC showed that the presynaptic action of the venom was temperature-dependent (4). More recently, we have observed that the presynaptic neurotoxicity of BNP on MPND is $\mathrm{Ca}^{2+}$-dependent and accompanied by a pronounced increase in the frequency of mepps and the presence of giant mepps (12).

$\mathrm{PLA}_{2}$ (E.C. 3.1.14) are $\mathrm{Ca}^{2+}$-dependent enzymes that catalyze the hydrolysis of phospholipids at position sn-2 (51). Snake venom PLA 2 occurs in groups I (Elapidae and Hydrophidae) and II (Viperidae). Group II contains the catalytically-active Asp49 
C. R. Borja-Oliveira et al. PURIFICATION AND N-TERMINAL SEQUENCING OF TWO PRESYNAPTIC NEUROTOXIC PLA2, NEUWIEDITOXIN-I AND NEUWIEDITOXIN-II, FROM Bothrops neuwied pauloensis (JARARACA PINTADA) VENOM. J. Venom. Anim. Toxins incl. Trop. Dis., 2007, 13, 1, p. 105

$\mathrm{PLA}_{2}$, as well as the Lys49 isoforms. The latter type of proteins are considered PLA 2 homologues since they are probably devoid of (or may have very low) catalytic activity. In addition to their enzymatic activity, venom $\mathrm{PLA}_{2}$ may have other actions, such as neurotoxicity and myotoxicity (25).

In the present work, two presynaptic neurotoxic PLA $\mathrm{PL}_{2}$, named neuwieditoxin-I (NeuTX-I) and neuwieditoxin-II (NeuTX-II), were isolated from BNP venom and partially sequenced. This is the first time to our knowledge that a pure presynaptically active neurotoxin such as NeuTX-I has been isolated from botropic venom and partially sequenced.

\section{MATERIALS AND METHODS}

\section{Reagents and venom}

Acetylcholine chloride, solvents (HPLC grade) and other reagents were obtained from Sigma and Aldrich Chemical Company (St Louis, MO, USA). Bothrops neuwiedi pauloensis venom, collected in the state of São Paulo, was provided by Butantan Institute (São Paulo, São Paulo State, Brazil). The venom was obtained from adult specimens, and was desiccated and stored at $2-4^{\circ} \mathrm{C}$.

\section{Purification of Neuwieditoxins I and II}

Molecular exclusion HPLC: Bothrops neuwiedi pauloensis venom (25mg) was loaded onto a Protein-Pak 300 SW (Waters, Milford, MA, USA) column $(0.78 \mathrm{~cm} \times 30 \mathrm{~cm})$ and eluted with $0.25 \mathrm{M}$ ammonium bicarbonate, $\mathrm{pH} 7.9$, at a flow rate of $0.3 \mathrm{ml} / \mathrm{min}$. The elution profile was monitored at $280 \mathrm{~nm}$ using a Waters 490 programmable multiwavelength detector (Waters, Milford, MA, USA); fractions were collected using a Foxy 200 automatic fraction collector (Isco, Inc., Lincoln, NE, USA). The chromatographic runs were recorded on a 746 data module dual channel recorder (Waters, Milford, MA, USA).

Reverse-phase HPLC: Lyophilized fractions from molecular exclusion HPLC were screened for neuromuscular activities and those of interest were then fractionated using a $\mu$ Bondapak C18 (Waters, MA, USA) column $(0.78 \mathrm{~cm} \times 30 \mathrm{~cm})$. The column was equilibrated with buffer $A(0.1 \%$ trifluoroacetic acid - TFA, in water) and the proteins were eluted with a linear gradient of buffer B $(0.035 \%$ TFA in $66 \%$ acetonitrile) at a flow rate of $1.0 \mathrm{ml} / \mathrm{min}$. The elution profile was monitored at $280 \mathrm{~nm}$. 
C. R. Borja-Oliveira et al. PURIFICATION AND N-TERMINAL SEQUENCING OF TWO PRESYNAPTIC NEUROTOXIC PLA2, NEUWIEDITOXIN-I AND NEUWIEDITOXIN-II, FROM Bothrops neuwied pauloensis (JARARACA PINTADA) VENOM. J. Venom. Anim. Toxins incl. Trop. Dis., 2007, 13, 1, p. 106

The fractions from reverse-phase HPLC were screened for neuromuscular activities. Those of interest were then pooled, lyophilized and stored at $-20^{\circ} \mathrm{C}$.

\section{Phospholipase $A_{2}$ activity}

$\mathrm{PLA}_{2}$ activity was measured using the assay previously described by Cho and Kezdy (7) and Holzer and Mackessy (20), modified for 96-well plates (3). The enzyme activity, expressed as the reaction initial velocity (Vo), was calculated based on the increase in absorbance after $20 \mathrm{~min}$. Absorbances at $425 \mathrm{~nm}$ were measured using a SpectraMax 340 multiwell plate reader (Molecular Devices, Sunnyvale, CA, USA).

\section{Electrophoresis}

Tricine-PAGE in a discontinuous gel and buffer system (45) was used to estimate the molecular mass of the proteins, in the presence or absence of dithiothreitol (DTT). Marker proteins were included in the runs and the gels were stained with coomassie blue.

\section{$\mathrm{N}$-terminal sequencing}

Direct sequencing of the $\mathrm{N}$-terminal was done with reduced and carboxymethylated protein, using a Procise protein sequencing system (Applied Biosystems, CA, USA). Phenylthiohydantoin amino acids were identified by comparing their retention times with those of 20 phenylthiohydatoin amino acid standards.

\section{Chick biventer cervicis (CBC) nerve-muscle preparation}

A protocol ( $\mathrm{n}^{\circ}$ 431-1) according to the Ethical Principles for Animal Research, established by the Brazilian College for Animal Experimentation (COBEA) and approved by the Institutional Committee for Ethics in Animal Research (State University of Campinas - UNICAMP), was used. The biventer cervicis was removed from chicks (which had been killed by exposure to halothane) as described by Ginsborg and Warriner (16) and mounted under a tension of $0.5 \mathrm{~g}$ in a $5 \mathrm{ml}$ organ bath containing aerated $\left(95 \% \mathrm{O}_{2}, 5 \% \mathrm{CO}_{2}\right)$ Krebs solution $\left(\mathrm{pH} 7.5,37^{\circ} \mathrm{C}\right)$ of the following composition (in $\mathrm{mM}$ ): $\mathrm{NaCl}, 118.6 ; \mathrm{KCl}, 4.69 ; \mathrm{CaCl}_{2}, 1.88 ; \mathrm{KH}_{2} \mathrm{PO}_{4}, 1.17 ; \mathrm{MgSO}_{4}$, 1.17; $\mathrm{NaHCO}_{3}, 25.0$; and glucose, 11.65. Indirect stimulation $(0.1 \mathrm{~Hz}, 0.2 \mathrm{~ms}, 6-7 \mathrm{~V})$ from a Grass S4 stimulator (Grass Instruments, Quincy, MA, USA) was used; muscle 
C. R. Borja-Oliveira et al. PURIFICATION AND N-TERMINAL SEQUENCING OF TWO PRESYNAPTIC NEUROTOXIC PLA2, NEUWIEDITOXIN-I AND NEUWIEDITOXIN-II, FROM Bothrops neuwied pauloensis (JARARACA PINTADA) VENOM. J. Venom. Anim. Toxins incl. Trop. Dis., 2007, 13, 1, p. 107

contractions and contractures were recorded via a force-displacement transducer (BG 25 GM, Kulite Semiconductor Products, Inc., Leonia, NJ, USA) coupled to a Gould RS 3400 recorder (Gould Inc., Cleveland, OH, USA). The preparations were allowed to stabilize for at least 15 min before the addition of fractions $(10 \mu \mathrm{g} / \mathrm{ml})$. Contractures to exogenously applied submaximal concentrations of acetylcholine $(110 \mu \mathrm{M})$ and $\mathrm{KCl}(13.4 \mathrm{mM})$ were obtained in the absence of nerve stimulation prior to the addition of toxins and at the end of the experiment in order to test for the presence of neurotoxic and myotoxic activities (18).

\section{Electrophysiological procedure}

Preparation: Left hemidiaphragm of mouse was prepared as previously described by Re et al. $(37,38)$. Briefly, Charles River male mice, 30-40 days old, were killed and the left hemidiaphragm was dissected together with a short length of phrenic nerve. The preparation was bathed in Krebs' solution of the following composition (mM): $\mathrm{NaCl}$ (133), $\mathrm{KCl}$ (4.7), $\mathrm{MgCl}_{2}$ (1.2), $\mathrm{CaCl}_{2}$ (7.2), $\mathrm{NaH}_{2} \mathrm{PO}_{4}$ (1.3), $\mathrm{NaHCO}_{3}$ (16.3), Glucose (7.8), $\mathrm{pH} 7.4$, gassed with $95 \% \mathrm{O}_{2}-5 \% \mathrm{CO}_{2}$ and kept at room temperature $\left(18-22^{\circ} \mathrm{C}\right)$. Concentrations of $\mathrm{MgCl}_{2}$ (5 to $\left.15 \mathrm{mM}\right)$ and $\mathrm{CaCl}_{2}(0.9$ to $2 \mathrm{mM})$ were adjusted in order to abolish the twitch of the muscle fiber.

The muscle was pinned on Sylgard resin, and placed on the stage of a Leitz inverted microscope. End-plates were visible by transillumination of the preparation using an optic fiber system. The preparation was equilibrated in saline for 30 minutes before starting the experiments.

End-plate signals: Spontaneous and evoked end-plate currents were recorded using a focal extracellular pipette pressed against the edge of an end-plate. Drummond $100 \mu \mathrm{l}$ measuring pipettes of soft glass $(1.4 \mathrm{~mm})$ were pulled with a Kopf $700 \mathrm{C}$ Puller, which had a final tip diameter ranging from 3 to $15 \mu \mathrm{m}$ and was fire polished with a Narishighe MF83 Microforge. After filling with physiological solution, the electrode was connected to a List LM EPC7 current to voltage converter. Pipette resistances were of $100-300 \mathrm{~K} \Omega$, and seal resistances, measured after pressing the pipette against the sarcolemma, ranged between $300-600 \mathrm{~K} \Omega$. The loose patch clamp method (47) enables a good control of the series resistance all over the experiment (40). Furthermore, the voltage of the muscle fiber is well monitored using the same technique and virtually clamped at the resting value. Indirect stimulation of the 
C. R. Borja-Oliveira et al. PURIFICATION AND N-TERMINAL SEQUENCING OF TWO PRESYNAPTIC NEUROTOXIC PLA2, NEUWIEDITOXIN-I AND NEUWIEDITOXIN-II, FROM Bothrops neuwied pauloensis (JARARACA PINTADA) VENOM. J. Venom. Anim. Toxins incl. Trop. Dis., 2007, 13, 1, p. 108

muscle was achieved by means of a suction electrode. Supramaximal square wave pulses of $0.1 \mathrm{~ms}$ duration at $2 \mathrm{~Hz}$ were applied via a DA analogic output of a PCL 818 card (Advantech). The signals were visualized on a Tektronix 5113 dual-beam storage oscilloscope and fed to the input stage of the PCL 818 analogue-to-digital converter mounted on a computer system (PC IBM) enabling a fully automated analysis of the data (39). The decay phase of the miniature end-plate currents (mepc's) was analyzed to calculate the decay time constant. The elaboration was carried out on the mepc decay part that fell within $10-90 \%$ of its peak amplitude. The function used was:

$$
\mathrm{I}_{\mathrm{t}}=\mathrm{I}_{\mathrm{O}} \exp ^{-\mathrm{t} / \tau}
$$

where $\mathrm{l}_{\mathrm{t}}$ is the current at time $\mathrm{t} ; \mathrm{I}_{\mathrm{O}}$ is the current at time zero, i.e. the peak current; and $\tau$ is the decay time constant. Marquardt's least-squares method was used for the fitting.

The parameters were obtained using the protocol previously described by Re et al. (38). The technique led to automatic evaluation of the mean $\tau$ value of the mepc's decay, the mean peak value of the miniature events (mepc), the spontaneous release frequency (f), and the mean epc's peak value (epc). The resting membrane potential (RMP) was measured using conventional intracellular microelectrodes (3M $\mathrm{KCl}$ ) connected to a P16 differential amplifier (GRASS).

\section{Statistical analysis}

Each experiment was repeated at least three times. Results were expressed as mean \pm standard error of mean (S.E.M.). Student's t-test was used for statistical analysis of the data, and values of $p<0.05$ indicated significance.

\section{RESULTS}

Bothrops neuwiedi pauloensis (BNP) venom was initially separated into 8 fractions by molecular exclusion (Figure 1A). Since the venom contains PLA 2 activity $(12.7 \mathrm{nmol} / \mathrm{min} / \mathrm{mg})$, this enzyme was assayed along the venom elution profile. Only fractions 2 and 3 , corresponding to the second and third peaks, had PLA 2 activity: 25.8 and $48.2 \mathrm{nmol} / \mathrm{min} / \mathrm{mg}$, respectively. 
C. R. Borja-Oliveira et al. PURIFICATION AND N-TERMINAL SEQUENCING OF TWO PRESYNAPTIC NEUROTOXIC PLA2, NEUWIEDITOXIN-I AND NEUWIEDITOXIN-II, FROM Bothrops neuwied pauloensis (JARARACA PINTADA) VENOM. J. Venom. Anim. Toxins incl. Trop. Dis., 2007, 13, 1, p. 109

In indirectly stimulated CBC preparations, only fraction 3, corresponding to the third peak, produced complete blockade without significantly inhibiting the responses to ACh and $\mathrm{KCl}$. At $10 \mu \mathrm{g} / \mathrm{ml}$, fraction 3 produced complete and irreversible neuromuscular blockade in $70 \pm 6 \mathrm{~min}$ at $37^{\circ} \mathrm{C}(n=4)$ (not shown). Low temperature $\left(20-24^{\circ} \mathrm{C}\right)$ abolished the neuromuscular action of this fraction $(n=3)$ (not shown).

After repurification of fraction 3 (Figure 1B), only fractions corresponding to peak c (5$7 \%$ of venom protein), namely NeuTX-I, and peak b (3.5\% of venom protein), namely NeuTX-II, induced neuromuscular blockade in CBC preparation. Tricine SDS-PAGE in the presence or absence of dithiothreitol showed that NeuTX-I and NeuTX-II had a molecular mass of $\sim 14$ and $\sim 28 \mathrm{kDa}$, respectively (Figure 1B, inset). NeuTX-I $(10 \mu \mathrm{g} / \mathrm{ml})$ produced complete neuromuscular blockade up to $80 \mathrm{~min}(\mathrm{n}=3)$, without inhibiting the responses to $\mathrm{ACh}$ and $\mathrm{KCl}$ (Figures $2 \mathrm{~A}, \mathrm{~B}$ and $\mathrm{D}$ ), whereas the response to $\mathrm{KCl}$ were partially inhibited after incubation with NeuTX-II $(10 \mu \mathrm{g} / \mathrm{ml})$ (Figures 2A, C and D).

The N-terminal sequences were determined up to the $36^{\text {th }}$ for NeuTX-I, and up to the $41^{\text {st }}$ for NeuTX-II amino acid residues (Figures 3 and 4).

To better clarify the possible molecular event involved in the NeuTX-I (the only toxin that induced complete neuromuscular blockade without inhibiting $\mathrm{ACh}$ and $\mathrm{KCl}-$ induced contracture) action, we studied the effects of the toxin $(5,10$ and $50 \mu \mathrm{g} / \mathrm{ml})$ on mouse neuromuscular junction using the loose patch clamp technique (LPC). The results obtained were summarized in Table 1 . The toxin induced an increase in the amplitude and frequency of the spontaneous release. Giant mepc's were frequently observed at NeuTX-I concentration of $10 \mu \mathrm{g} / \mathrm{ml}$ (Figure 5). After this apparent facilitation, a complete block of the evoked release was always observed (Figures 6 a, b, c). Usually, the recovery of the evoked signals was incomplete after the final wash out. However, the block was overcome by adding calcium to the physiological solution (Figures $6 \mathrm{~d}, \mathrm{e}$ ).

During treatments with NeuTX-I, resting membrane potential values were not different from those obtained during control (toxin-free medium) experiments. 


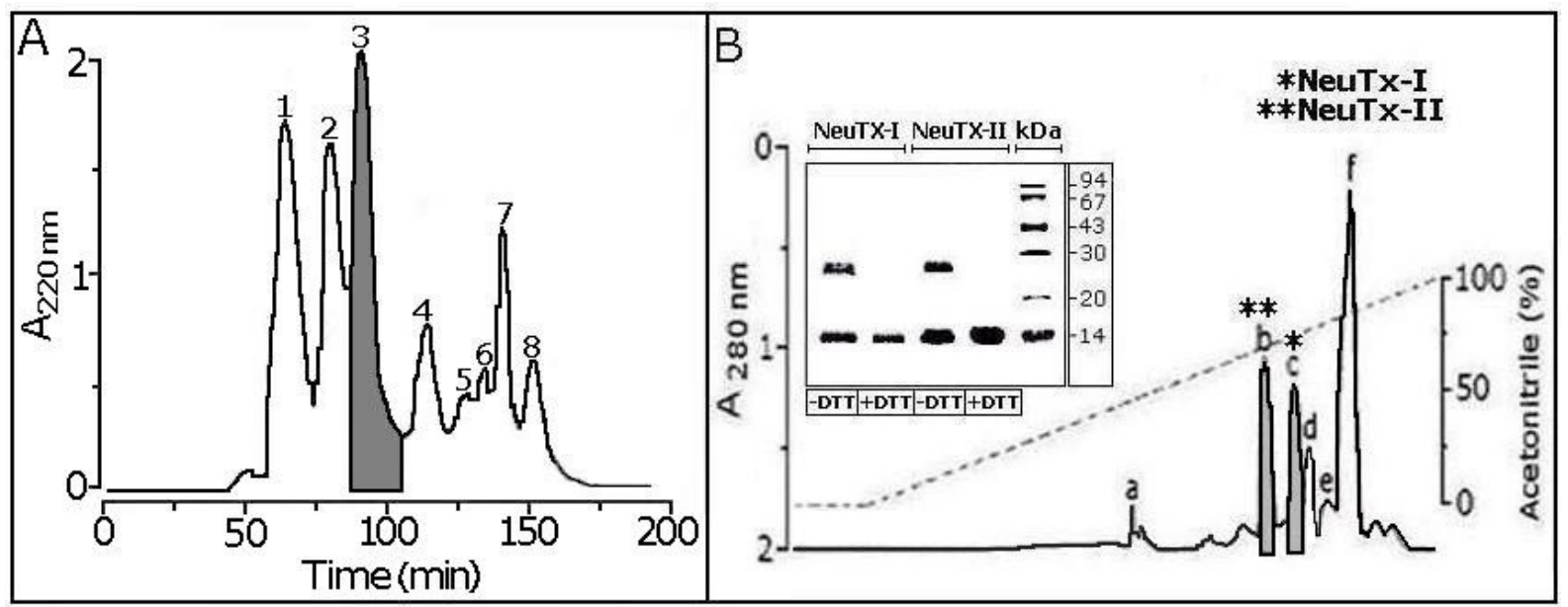

Figure 1. Purification of NeuTXs-I and II. A: Molecular exclusion HPLC of Bothrops neuwiedi pauloensis venom $(25 \mathrm{mg})$. Fractions were collected and the elution profile was monitored at $280 \mathrm{~nm}$. B: Repurification of fraction 3 by reverse phase HPLC. NeuTX-I $\left(^{*}\right)$ was recovered in peak $c$ and NeuTX-II $\left(^{* *}\right)$ was recovered in peak b. The inset shows a Tricine-SDS-PAGE gel of the toxins in the absence and presence of dithiothreitol (DTT).

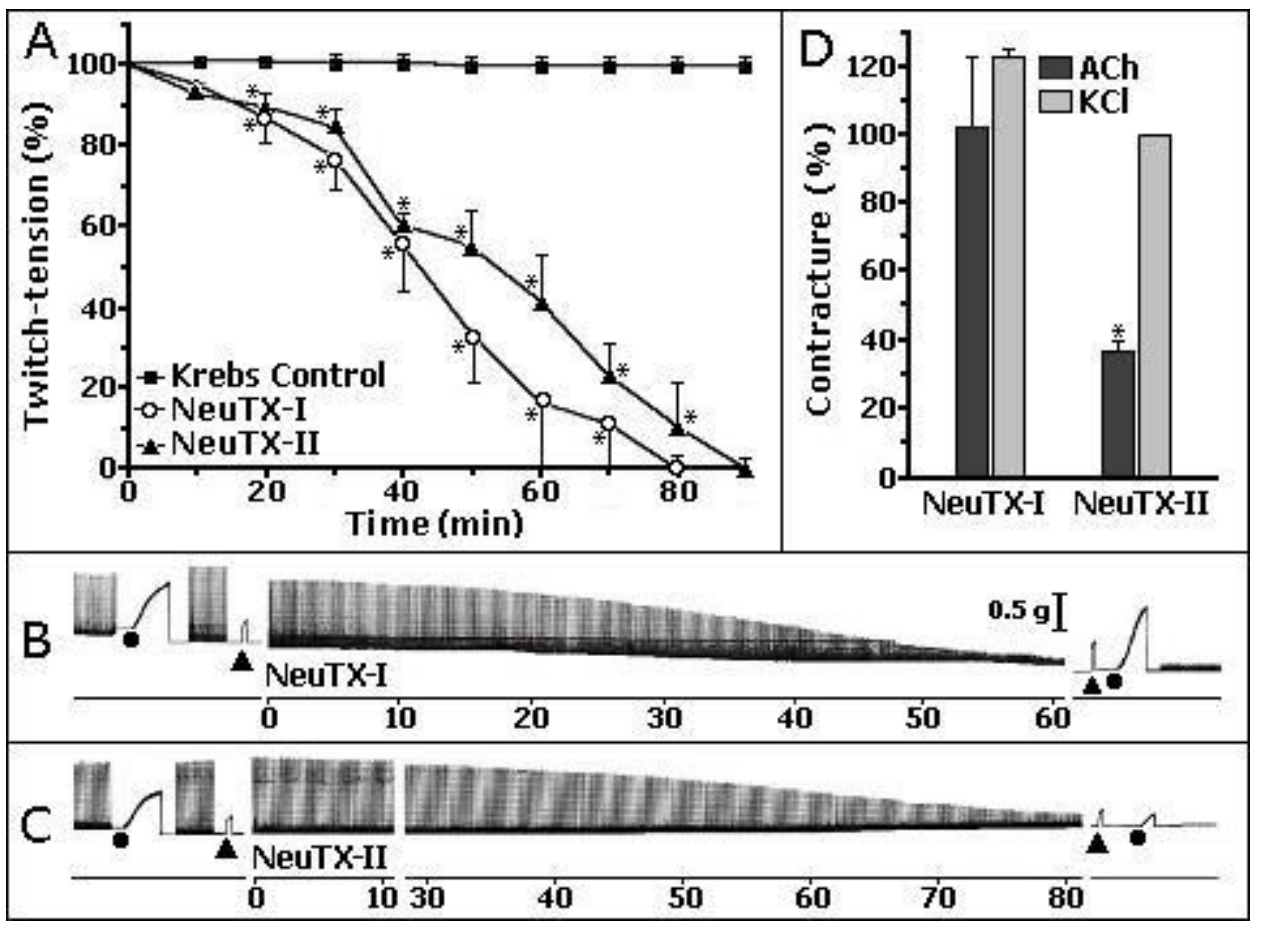

Figure 2. Neuromuscular blockade of chick biventer cervicis preparations at $37^{\circ} \mathrm{C}$ by NeuTXs-I and II. A: Time-dependent blockade produced by each toxin $(10 \mu \mathrm{g} / \mathrm{ml})$, on indirectly stimulated preparations, compared to the Krebs control $\left({ }^{*} p<0.05\right)$. Each point represents the mean \pm S.E.M. of $3-5$ experiments. $\mathrm{B}$ and $\mathrm{C}$ : Representative recordings of the responses of indirectly stimulated chick preparation to NeuTX-I and NeuTX-II $(10 \mu \mathrm{g} / \mathrm{ml})$, respectively. Responses to exogenous acetylcholine $(\boldsymbol{\Delta}, 110 \mu \mathrm{M})$ and $\mathrm{KCl}(\bullet, 13.4 \mathrm{mM})$ were obtained before and after the addition of toxins. Note that, in contrast to the response to $\mathrm{KCl}$, response to acetylcholine after the blockade by NeuTX-II was still identical to the control. This result is representative of 3 experiments. D: Muscle contractures to $\mathrm{KCl}$ $(13.4 \mathrm{mM})$ and acetylcholine $(\mathrm{ACh}, 110 \mu \mathrm{M})$ after $120 \mathrm{~min}$ incubation with each toxin $(10 \mu \mathrm{g} / \mathrm{ml})(\mathrm{mean} \pm$ S.E.M. of 3-5 experiments), expressed as a percentage of the pre-toxin values $\left({ }^{*} p<0.05\right)$. 


\begin{tabular}{|c|c|c|c|c|c|c|c|c|c|c|c|c|c|c|c|c|c|c|c|c|c|c|c|c|c|c|c|c|c|c|c|c|c|c|c|c|c|}
\hline & 1 & & & & 5 & & & & & 10 & & & & & 15 & & & & & 20 & & & & & 25 & & & & & 30 & & & & & 35 & & H\% \\
\hline 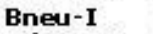 & 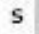 & $\mathrm{L}$ & $v$ & $E$ & L & G & K & $M$ & 1 & L & Q & $E$ & $\mathbf{T}$ & G & - & K & $N$ & $P$ & $v$ & $\mathbf{T}$ & $s$ & $Y$ & $G$ & A & $Y$ & G & c & $N$ & c & G & v & L & G & $R$ & 6 & & \\
\hline -I & $s$ & L & $F$ & E & L & G & $\kappa$ & $M$ & I & L & Q & $E$ & $\mathrm{~T}$ & $G$ & - & K & $v$ & $P$ & A & K & $s$ & $Y$ & G & A & $\gamma$ & G & c & $N$ & c & G & $\mathrm{v}$ & L & G & $\mathbf{R}$ & 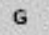 & & \\
\hline I & $\mathrm{s}$ & L & F & $E$ & L & G & K & $M$ & I & $L$ & 0 & E & $\mathrm{T}$ & G & - & K & & $P$ & A & $\kappa$ & 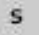 & $Y$ & G & A & $Y$ & G & & $\mathrm{N}$ & c & G & $\mathrm{v}$ & L & 3 & R & G & & \\
\hline 7 & $\mathrm{~s}$ & $L$ & $F$ & E & L & G & K & $M$ & I & L & $Q$ & $\mathbf{E}$ & $\mathbf{T}$ & $G$ & - & K & $N$ & $P$ & A & $\kappa$ & $\mathrm{s}$ & 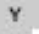 & G & A & $Y$ & G & c & $\mathrm{N}$ & C & G & $\mathrm{v}$ & L & $G$ & R & G & 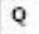 & \\
\hline cin & $N$ & L & I & $Q$ & $\Sigma$ & G & $N$ & $M$ & 1 & 5 & A & $M$ & $\mathbf{T}$ & G & K & s & s & 1 & A & - & - & 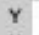 & A & s & $Y$ & G & c & Y & c & G & w & G & $G$ & K & G & $Q$ & \\
\hline & $N$ & L & L & Q & $F$ & $N$ & K & $M$ & 1 & K & $E$ & $E$ & $\mathbf{T}$ & G & K & $N$ & I & $\mathrm{P}$ & $F$ & $Y$ & - & A & 1 & - & r & $G$ & c & r & C & G & $w$ & G & G & $Q$ & G & K & \\
\hline II & s & L & I & E & F & A & K & $M$ & I & L & E & $E$ & $\mathrm{~T}$ & K & - & $R$ & L & $P$ & $\mathrm{~F}$ & $P$ & $Y$ & $x$ & T & $\mathrm{T}$ & $Y$ & G & $c$ & $Y$ & c & G & $w$ & G & $G$ & $Q$ & G & 0 & \\
\hline & $s$ & L & $L$ & E & $F$ & G & $M$ & $M$ & I & L & G & $E$ & $\mathrm{~T}$ & G & K & $\mathrm{N}$ & $\mathrm{P}$ & L & $\mathrm{T}$ & $s$ & $\mathrm{~F}$ & $Y$ & S & $F$ & $\gamma$ & G & 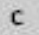 & $Y$ & $c$ & G & $\mathrm{v}$ & $G$ & $G$ & K & G & r & \\
\hline$x$ & $N$ & $L$ & L & $Q$ & $E$ & $N$ & K & $M$ & I & K & I & M & $\mathbf{T}$ & K & K & $\mathrm{N}$ & A & I & $P$ & $F$ & 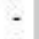 & $Y$ & $\mathbf{S}$ & $\mathbf{S}$ & $Y$ & G & & y & c & G & w & G & 6 & Q & G & & \\
\hline & $\mathrm{H}$ & $L$ & L & Q & 1 & $\mathrm{~N}$ & K & $M$ & I & K & $E$ & $E$ & $\mathbf{T}$ & G & $\kappa$ & $\mathrm{N}$ & A & 1 & P & $F$ & - & 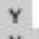 & A & F & $Y$ & G & 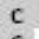 & Y & c & G & G & G & & $Q$ & G & & \\
\hline 11 & $s$ & $M$ & $Y$ & $Q$ & L & w & $\mathrm{H}$ & $M$ & I & L & Q & $\mathrm{E}$ & $\mathbf{T}$ & $\mathbf{G}$ & - & K & $N$ & A & $\mathrm{v}$ & $P$ & $s$ & $Y$ & G & L & Y & $G$ & c & $N$ & c & G & $v$ & G & 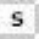 & R & $G$ & $\kappa$ & 48 \\
\hline xin & $\mathrm{N}$ & L & v & $Q$ & 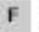 & $s$ & $Y$ & L & 1 & 0 & 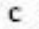 & A & $\mathrm{N}$ & $n$ & G & 1 & F & P & 1 & $w$ & $\mathrm{H}$ & $Y$ & & D & $r$ & & & $Y$ & C & G & A & G & & $S$ & G & & \\
\hline
\end{tabular}

Figure 3. Amino acid sequence alignment of NeuTX-I with myotoxic and presynaptic neurotoxic PLA 2 toxins. Bothropstoxin-II (BthTX-II), from B. jararacussu (36); Bneu-I, from B. neuwiedi (15); bothropstoxin-I (BthTX-I), from B. jararacussu venom (8); piratoxins (PrTXs), from B. pirajai venom (48); Basp-II, from Bothrops asper venom (14); BnSP7, from B. neuwiedi (46); caudoxin, a presynaptic neurotoxin from Bitis caudalis (52); taipoxin- $\alpha$, a presynaptic neurotoxin from Oxyuranus s. scutellatus (31); ACLMT, a myotoxin from Agkistrodon contortrix laticinctus (22); agkistrodotoxin (AgkisTX), a presynaptic neurotoxin from Agkistrodon halys pallas (28); Basp-III, from Bothrops asper venom (23); ammodytoxin A (AtxA), from Vipera ammodytes ammodytes (42); trimucrotoxin (TrimucrTX), from Trimeresurus mucrosquamatus (49); basic component of mojavetoxin (Mojave-B), from Crotalus

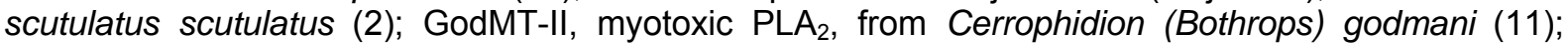
notexin, from Notechis scutatus scutatus (17); basic component of crotoxin (CroTX), from Crotalus durissus terrificus (1); $\beta$-bungarotoxin ( $\beta$-buTX), from Bungarus multicinctus $(26,27)$. Conserved residues are in gray. The percentage homology $(\mathrm{H} \%)$ is also shown.

\begin{tabular}{|c|c|c|c|c|c|c|c|c|c|c|c|c|c|c|c|c|c|c|c|c|c|c|c|c|c|c|c|c|c|c|c|c|c|c|c|c|c|c|c|c|c|c|}
\hline & 1 & & & & 5 & & & & & 10 & & & & & 15 & & & & & 20 & & & & & 25 & & & & & 30 & & & & & 35 & & & & & 40 & & $4^{\circ}$ \\
\hline s & S & L & $F$ & E & & G & K & $M$ & I & & Q & $\mathrm{t}$ & $\mathrm{I}$ & - & G & K & $N$ & $P$ & A & K & s & $Y$ & $G$ & A & $Y$ & $G$ & c & $\mathrm{N}$ & c & $G$ & $\mathrm{v}$ & L & G & $\mathbf{R}$ & G & Q & $\mathbf{P}$ & K & D & A & & \\
\hline & s & L & $F$ & E & L & G & $n$ & 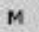 & 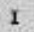 & & $Q$ & $E$ & $T$ & - & G & $\kappa$ & $\mathrm{N}$ & p & A & K & 5 & $Y$ & $G$ & A & $Y$ & $G$ & c & $\mathrm{N}$ & c & $G$ & v & L & $\bar{G}$ & $\mathbf{R}$ & $G$ & K & $P$ & $\mathrm{~K}$ & D & A & I & \\
\hline $\mathbf{I I}$ & 5 & L & F & $\bar{E}$ & 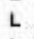 & $G$ & $\kappa$ & e & & L & 0 & & I & & $G$ & K & 1 & p & A & 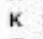 & $s$ & $Y$ & $G$ & A & $Y$ & $G$ & c & $\mathrm{N}$ & C & $G$ & $\mathrm{v}$ & L & $G$ & $\mathbf{R}$ & 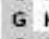 & K & $p$ & K & 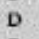 & A & & \\
\hline $\mathrm{C}$ & 5 & L & L & E & $\mathrm{L}$ & G & K & . & 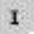 & L & K & $E$ & I & - & G & $K$ & $N$ & A & $I$ & $\mathbf{T}$ & $S$ & $Y$ & G & S & $Y$ & $G$ & c & $\mathrm{N}$ & c & $G$ & w & $G$ & H & $\mathbf{R}$ & G & $Q$ & $P$ & K & D & A & $\mathbf{T}$ & \\
\hline -B & $s$ & L & L & Q & $F$ & $N$ & K & 8 & f. & K & F & E & $\mathbf{T}$ & . & R & K & $N$ & A & $\mathrm{v}$ & $P$ & F & $Y$ & A & F & $Y$ & $G$ & c & $Y$ & c & G & w & G & G & $Q$ & R & $x$ & $p$ & K & D & A & & \\
\hline II & D & L & $w$ & $Q$ & w & G & $Q$ & $M$ & 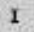 & L & K & E & $T$ & 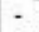 & $G$ & $\kappa$ & L & $P$ & $F$ & $P$ & $r$ & $Y$ & $T$ & $\mathbf{T}$ & Y & $G$ & c & $Y$ & c & G & w & $G$ & G & $\mathbf{R}$ & G & K & $P$ & $v$ & D & $P$ & I & \\
\hline & $s$ & L & $\mathrm{v}$ & $E$ & L & G & 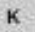 & 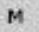 & & 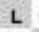 & Q & $E$ & $\mathrm{I}$ & - & G & $\kappa$ & $N$ & $P$ & $\mathrm{v}$ & $\mathbf{I}$ & $S$ & $Y$ & $G$ & A & Y & G & C & $N$ & c & G & $\mathrm{v}$ & $L$ & G & $\mathbf{R}$ & G & K & $P$ & K & D & A & & \\
\hline & H & L & L & Q & $\mathrm{F}$ & $N$ & K & $M$ & 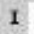 & K & $E$ & $E$ & $\mathrm{~T}$ & - & G & K & $N$ & A & 1 & $P$ & $F$ & $Y$ & A & $F$ & $y$ & G & c & $Y$ & C & G & G & 6 & G & $Q$ & G & K & $P$ & K & D & G & I & \\
\hline & $N$ & L & L & $Q$ & $\mathrm{~F}$ & $\mathrm{~N}$ & K & $M$ & & K & E & $\mathrm{E}$ & $\mathbf{I}$ & - & G & & $\mathrm{N}$ & I & $p$ & F & $Y$ & A & $F$ & . & $Y$ & G & & 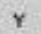 & $c$ & G & w & G & G & Q & $G$ & K & P & k & & $\mathbf{G}$ & & \\
\hline & $\mathrm{N}$ & L & I & $Q$ & F & G & $\mathrm{N}$ & $M$ & & $S$ & A & $M$ & $\mathrm{~T}$ & - & G & & $\mathrm{s}$ & s & L & A & $x$ & $Y$ & A & $s$ & Y & G & & $Y$ & $\mathrm{C}$ & $G$ & 1 & G & $G$ & K & G & & & K & 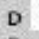 & 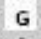 & & \\
\hline & s & $M$ & $Y$ & $Q$ & L & w & $\mathrm{H}$ & $M$ & 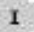 & L & $Q$ & $E$ & $\mathrm{~T}$ & - & G & 1 & $\mathrm{~N}$ & A & $\mathrm{v}$ & $P$ & S & $Y$ & G & L & r & G & $c$ & $\mathrm{~N}$ & c & $G$ & $\mathrm{v}$ & $G$ & s & $\mathbf{R}$ & G & $\mathrm{K}$ & $p$ & K & D & A & T & \\
\hline & $N$ & L & L & Q & $F$ & G & F & - & 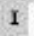 & $\mathbf{R}$ & c & 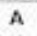 & $N$ & R & 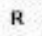 & 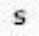 & $\mathbf{R}$ & $P$ & $\mathrm{v}$ & w & $H$ & $Y$ & $M$ & D & $Y$ & -1 & c & $Y$ & 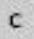 & G & K & $G$ & G & s & G & $\mathrm{T}$ & $p$ & K & D & G & T & \\
\hline
\end{tabular}

Figure 4. N-terminal amino acid sequence alignment of NeuTX-II with myotoxic and presynaptic neurotoxic PLA $\mathrm{P}_{2}$ toxins. Basp-III, from Bothrops asper venom (23); BnSP7, from B. neuwiedi (46); bothropstoxin-I (BthTX-I), from B. jararacussu venom (8); piratoxins (PrTXs), from B. pirajai venom (48); Basp-II, from Bothrops asper venom (14); ACLMT, a myotoxin from Agkistrodon contortrix laticinctus (22); basic component of crotoxin (CroTX), from Crotalus durissus terrificus (1); trimucrotoxin (TrimucrTX), from Trimeresurus mucrosquamatus (49); ammodytoxin A (AtXA), from Vipera ammodytes ammodytes (42); bothropstoxin-II (BthTX-II), from B. jararacussu (36); Bneu-I, from B. neuwiedi (15); basic component of mojavetoxin (Mojave-B), from Crotalus scutulatus scutulatus (2); agkistrodotoxin (AgkisTX), from Agkistrodon halys pallas (28); caudoxin, from Bitis caudalis (52);

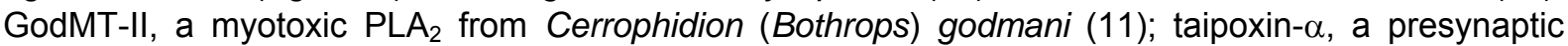
neurotoxin from Oxyuranus s. scutellatus (31); $\beta$-bungarotoxin ( $\beta$-buTX), from Bungarus multicinctus $(26,27)$; notexin, from Notechis scutatus scutatus (17). Conserved residues are in gray. The percentage homology $(\mathrm{H} \%)$ is also shown. 
C. R. Borja-Oliveira et al. PURIFICATION AND N-TERMINAL SEQUENCING OF TWO PRESYNAPTIC NEUROTOXIC PLA2, NEUWIEDITOXIN-I AND NEUWIEDITOXIN-II, FROM Bothrops neuwied pauloensis (JARARACA PINTADA) VENOM. J. Venom. Anim. Toxins incl. Trop. Dis., 2007, 13, 1, p. 112

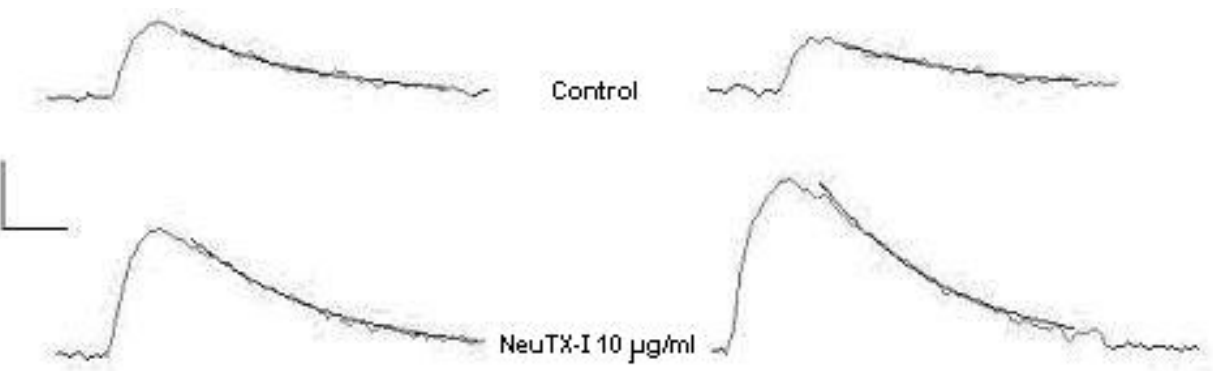

Figure 5. Spontaneous miniature end-plate currents recorded at mouse neuromuscular junction. The figure shows digitized raw data related to control and treatment with NeuTX-I concentration of $10 \mu \mathrm{g} / \mathrm{ml}$. Note the presence of giant mepc's. Calibration bars, vertical: $250 \mathrm{pA}$, horizontal: $1 \mathrm{~ms}$.

A

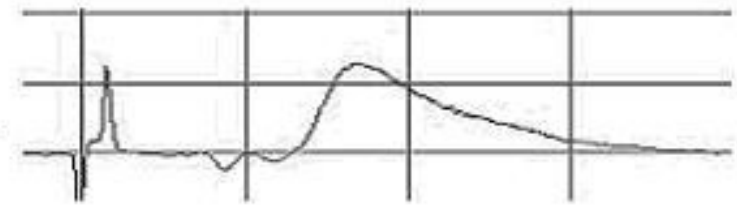

B
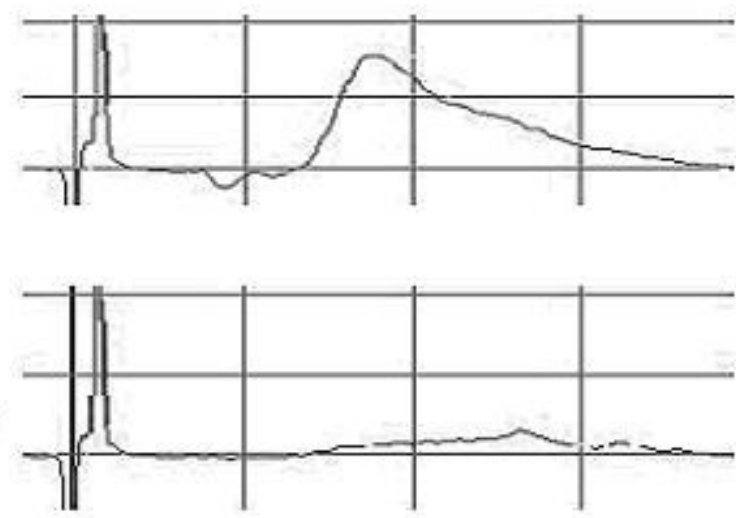

$\mathrm{D}$
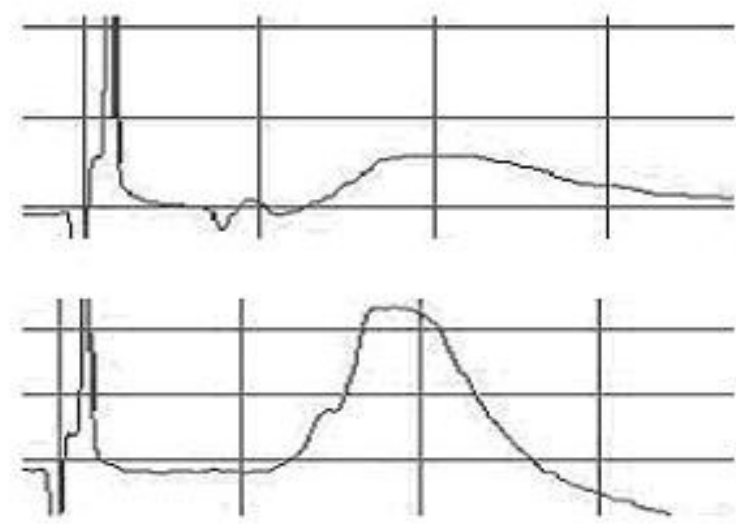

Figure 6. Averaged signals obtained by 200 evoked end-plate currents recorded at mouse neuromuscular junction. The figure shows digitized raw data related to control $(A)$, treatment with NeuTX-I concentration of $5 \mu \mathrm{g} / \mathrm{ml}$ (B) and $10 \mu \mathrm{g} / \mathrm{ml}$ (C); the effects obtained after a wash out (D) and a subsequent flow of a physiological solution with calcium concentration increased from 1 to $1.5 \mathrm{mM}(\mathrm{E})$. Calibration bars, vertical: 2nA, horizontal: $2 \mathrm{~ms}$. 
C. R. Borja-Oliveira et al. PURIFICATION AND N-TERMINAL SEQUENCING OF TWO PRESYNAPTIC NEUROTOXIC PLA2, NEUWIEDITOXIN-I AND NEUWIEDITOXIN-II, FROM Bothrops neuwied pauloensis (JARARACA PINTADA) VENOM. J. Venom. Anim. Toxins incl. Trop. Dis., 2007, 13, 1, p. 113

Table 1. Effects of NeuTX-I on mouse neuromuscular junction.

\begin{tabular}{|c|c|c|c|c|c|}
\hline & Control Values & $\begin{array}{c}\text { NeuTX-I } \\
5 \mu \mathrm{g} / \mathrm{ml}\end{array}$ & $\begin{array}{l}\text { NeuTX-I } \\
10 \mu \mathrm{g} / \mathrm{ml}\end{array}$ & $\begin{array}{l}\text { NeuTX-I } \\
50 \mu \mathrm{g} / \mathrm{ml}\end{array}$ & Wash Out \\
\hline epc (nA) & $1.57( \pm 0.58 ; 5)$ & $+16.9( \pm 7.62 ; 5)^{*}$ & $-65.2( \pm 20.0 ; 5)$ & $-84.0( \pm 8.61 ; 5)$ & $-69.8( \pm 16.8 ; 5)$ \\
\hline mepc (nA) & $0.20( \pm 0.08 ; 5)$ & $+19.7( \pm 19.8 ; 5)^{*}$ & $+30.6( \pm 40.9 ; 5)^{*}$ & $+47.1( \pm 57.3 ; 5)^{\star}$ & $+63.5( \pm 92.6 ; 5)^{*}$ \\
\hline $\mathbf{f}(\mathrm{Hz})$ & $2.11( \pm 0.81 ; 5)$ & $+14.2( \pm 11.4 ; 5)^{*}$ & $+8.9( \pm 20.8 ; 5)^{*}$ & $+18.4( \pm 52.0 ; 5)^{\star}$ & $-2.52( \pm 28.9 ; 5)^{*}$ \\
\hline$\tau(\mathbf{m s})$ & $1.16( \pm 0.13 ; 5)$ & $+1.36( \pm 7.75 ; 5)^{*}$ & $+0.64( \pm 15.1 ; 5)^{*}$ & $+4.7( \pm 17.5 ; 5)^{\star}$ & $-1.84( \pm 9.42 ; 5)^{*}$ \\
\hline
\end{tabular}

Values show the effects of the indicated NeuTX-I concentrations on four parameters related to the function of mouse neuromuscular junction compared with control and final wash out. The amplitudes of the evoked (epc) and spontaneous (mepc) release, the frequency of the quantal release $(\mathbf{f})$ and the mepc's decay time constant $(\tau)$ were analyzed. Data were expressed as mean percentage variations in respect to mean control values. Standard deviations and number of experiments are indicated between parentheses.

* Indicates non-significant differences. Values in bold indicate significant mean with $p<0.05$.

\section{DISCUSSION}

Although neurotoxicity has been demonstrated in vitro $(4,5,9,10,12,44,46,53)$ and in vivo $(9,53)$ for various Bothrops venoms, there is no conclusive evidence for such an effect after snakebite in humans. In vitro, the neurotoxicity of BNP venom is mainly presynaptic $(4,5,12,44,53)$, although its potency varies from sample to sample (5).

Presynaptic inhibition is conveniently studied using dissected BCP preparation. A pure presynaptically active neurotoxin would abolish nerve-evoked twitches, without affecting responses to cholinoceptor agonists or the responses to direct muscle stimulation, but would not affect the responses to elevated $\mathrm{K}^{+}$concentration (18). As a pure presynaptically neurotoxin, NeuTX-I induced complete neuromuscular blockade without inhibiting the responses to $\mathrm{ACh}$ and $\mathrm{KCl}$. Consequently, its effects were studied using loose patch clamp technique on a mammalian neuromuscular junction. The electrophysiological data were indicative of a pure presynaptic effect. 
C. R. Borja-Oliveira et al. PURIFICATION AND N-TERMINAL SEQUENCING OF TWO PRESYNAPTIC NEUROTOXIC PLA2, NEUWIEDITOXIN-I AND NEUWIEDITOXIN-II, FROM Bothrops neuwied pauloensis (JARARACA PINTADA) VENOM. J. Venom. Anim. Toxins incl. Trop. Dis., 2007, 13, 1, p. 114

After an initial facilitation leading to depletion of ACh release, a complete calciumdependent blockade was observed. The presynaptic action is confirmed by the constancy of the mepc's decay time, i.e. the rate constant of the receptor-ion channel complex conformational change, reflecting the closing of the ACh-sensitive channels $(24,29)$ at the postsynaptic sites.

In general, snake venoms contain a mixture of toxins active at prejunctional and postjunctional sites, as well as myotoxic components. Therefore, probably more than one component is capable of contributing to the neuromuscular action produced by the venom. Myotoxic components reduce the response of biventer cervicis muscle to exposure to elevated $\mathrm{K}^{+}$concentration and/or initiate contractures in the muscle (18). These effects were produced by BNP venom (4) and NeuTX-II.

In previous reports, the neuromuscular blocking effect of BNP venom in BCP and MPND was temperature and $\mathrm{Ca}^{2+}$-dependent and this fact also indicated that enzymatic activity is necessary for neuromuscular action $(4,12)$. The neuromuscular blocking effect of the fraction corresponding to peak 3, from the molecular exclusion step, which showed PLA ${ }_{2}$ activity and revealed NeuTX-I and NeuTX-II after reversephase HPLC, was temperature-dependent, indicating that its neurotoxicity may require enzymatic activity, as suggested for the venom (4).

This is the first report of purification and N-terminal sequence of presynaptic PLA 2 toxins from Bothrops venom. Several snake presynaptic $\mathrm{PLA}_{2}$, which produce the same pharmacological action of NeuTX-I in CBC at low concentrations $(\leq 10 \mu \mathrm{g}$ of toxin/ml), have been described, such as the presynaptic PLA ${ }_{2}$ caudoxin (30) from the venom of Bitis caudalis, which shares $54 \%$ homology with NeuTX-I. On the other hand, NeuTX-II shares $62 \%$ homology with the basic component of crotoxin, a potent neurotoxin from the venom of the South American rattlesnake Crotalus durissus terrificus. Crotoxin is a $\beta$-neurotoxin consisting of a heterodimer of a non-toxic, nonenzymatic acidic protein, named crotapotin, and a basic Asp-49 protein with PLA 2 activity. The $P L A_{2}$ is a single polypeptide chain of 123 amino acids with considerable similarity to other $\mathrm{PLA}_{2}$, while crotapotin consists of three polypeptides linked by several disulfide bridges (1).

A recent comparative study of the pharmacological activities of $B$. insularis, $B$. neuwiedi and $C$. d. terrificus in chick neuromuscular preparations (44) indicated that $B$. neuwiedi and $B$. insularis venoms may contain components that act 
C. R. Borja-Oliveira et al. PURIFICATION AND N-TERMINAL SEQUENCING OF TWO PRESYNAPTIC NEUROTOXIC PLA2, NEUWIEDITOXIN-I AND NEUWIEDITOXIN-II, FROM Bothrops neuwied pauloensis (JARARACA PINTADA) VENOM. J. Venom. Anim. Toxins incl. Trop. Dis., 2007, 13, 1, p. 115

presynaptically at the skeletal neuromuscular junction in a manner similar to $C$. $d$. terrificus venom and its main toxin, crotoxin. These conclusions were based on several evidences, such as the blockade of twitch-tension by $B$. neuwiedi and $B$. insularis venoms without affecting the response to the cholinoceptor agonist, thus suggesting a predominant presynaptic action. These authors also pointed out the persistence of $\mathrm{KCl}$-induced contractures after neuromuscular blockade and the fact that at low concentrations both venoms were incapable of increasing creatine kinase activity.

The initial work on the neuromuscular blocking action of bothropic venoms by Rodrigues-Simioni et al. (43) led to the discovery of bothropstoxin-I (21), a myotoxin that has since been widely studied $(19,34,35)$. The presence of a presynaptic PLA 2 in $B$. $n$. pauloensis venom was expected, since several reports had already indicated that this venom had presynaptic neurotoxicity $(4,5,12,44,53)$.

The fact that NeuTX-I has GIn-4 (Q-4), Phe-5 (F-5) and Tyr-28 (Y-28), and that NeuTX-II has Phe-5 (F-5) and Tyr-28 (Y-28), amino acid residues conserved in all Asp-49 (D-49) PLA 2 variants purified so far, strongly suggests that both toxins are

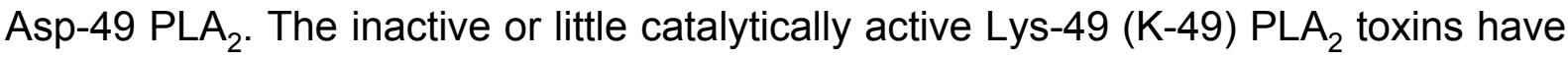
Leu-5 (L-5) for Phe-5 (F-5) and Asn-28 (N-28) for Tyr-28 (Y-28). The presence of Asp-49 is essential for effective hydrolysis of phospholipids. Besides Asp-49, the presence of Tyr-28, Gly-30 (G-30) and Gly-32 (G-32) is involved in the catalysis (50). NeuTX-I and NeuTX-II have Gly-30 and Gly-32, but Lys-49 toxins such as BnSP-7, a myotoxic PLA 2 from B. n. pauloensis venom $(13,32,46)$, besides bothropstoxin-I, piratoxins, Basp-II and Bneu, have Leu-32 (L-32) for Gly-32. In addition, the fraction that originated NeuTX-I and NeuTX-II, third peak from HPLC molecular exclusion elution profile, had PLA $\mathrm{P}_{2}$ activity and its blocking action was temperature-dependent. Loose patch clamp confirmed the calcium-dependent blockade produced by NeuTXI. All these findings together suggest that enzymatic activity is required for the pharmacological effects observed. Moreover, NeuTX-I and NeuTX-II may be the main components responsible for the neuromuscular blocking action of BNP venom. Based on our findings, the new toxins, NeuTX-I and NeuTX-II probably belong to two classes of $\mathrm{PLA}_{2}$ toxins: (1) group II, which include those toxins isolated from Viperinae and Crotalinae snake venoms; (2) $\beta$-neurotoxins group, which include presynaptic neurotoxic PLA 2 toxins. 
C. R. Borja-Oliveira et al. PURIFICATION AND N-TERMINAL SEQUENCING OF TWO PRESYNAPTIC NEUROTOXIC PLA2, NEUWIEDITOXIN-I AND NEUWIEDITOXIN-II, FROM Bothrops neuwied pauloensis (JARARACA PINTADA) VENOM. J. Venom. Anim. Toxins incl. Trop. Dis., 2007, 13, 1, p. 116

Although the neurotoxic action of Bothrops venoms is not a clinical problem, an understanding of the effects of other species may provide insights into a variety of physiological processes. Snake presynaptic neurotoxins with $\mathrm{PLA}_{2}$ activity affect the release of $\mathrm{ACh}$ and block the neurotransmission in an unknown way. Once their mechanism of action is firmly established, presynaptic $\mathrm{PLA}_{2}$ neurotoxins could be employed as tools to investigate specific aspects of neuroexocytosis. In addition, the isolation, identification, and pharmacological and biochemical characterization of $\mathrm{PLA}_{2}$ enzymes help to understand their structure-function relationships, which can be useful in developing prototypes of novel tools and pharmaceutical drugs (33).

\section{ACKNOWLEDGEMENTS}

The present work was supported by The State of São Paulo Research Foundation (FAPESP), National Council for Scientific and Technological Development (CNPq), The Coordination for the Improvement of Higher Education Personnel (CAPES), and Education and Research Foundation (FAEP-UNICAMP). The authors gratefully thank Gildo Bernardo Leite for technical assistance, and Butantan Institute for providing the venom sample.

\section{REFERENCES}

1 AIRD SD., KAISER II., LEWIS RV., KRUGGEL WG. A complete amino acid sequence for the basic subunit of crotoxin. Arch. Biochem. Biophys., 1986, 249, 296-300.

2 AIRD SD., KRUGGEL WG., KAISER II. Amino acid sequence of the basic subunit of Mojave toxin from the venom of the Mojave rattlesnake (Crotalus s. scutulatus). Toxicon, 1990, 28, 669-73.

3 BEGHINI DG., TOYAMA MH., HYSLOP S., SODEK L., NOVELLO JC., MARANGONI $S$. Enzymatic characterization of a novel phospholipase $\mathrm{A}_{2}$ from Crotalus durissus cascavella rattlesnake (maracambóia) venom. J. Protein Chem., 2000, 19, 603-7. 4 BORJA-OLIVEIRA CR., DURIGON AM., VALLIN ACC., TOYAMA MH., SOUCCAR C., MARANGONI S., RODRIGUES-SIMIONI L. The pharmacological effects of Bothrops neuwiedi pauloensis (jararaca-pintada) snake venom on avian neuromuscular transmission. Braz. J. Med. Biol. Res., 2003, 36, 617-24.

5 BORJA-OLIVEIRA CR., SOARES AM., ZAMUNER SR., HYSLOP S., GIGLIO JR., PRADO-FRANCESCHI J., RODRIGUES-SIMIONI L. Intraspecific variation in the neurotoxic and myotoxic activities of Bothrops neuwiedi snake venoms. J. Venom. Anim. Toxins, 2002, 8, 88-101. 
C. R. Borja-Oliveira et al. PURIFICATION AND N-TERMINAL SEQUENCING OF TWO PRESYNAPTIC NEUROTOXIC PLA2, NEUWIEDITOXIN-I AND NEUWIEDITOXIN-II, FROM Bothrops neuwied pauloensis (JARARACA PINTADA) VENOM. J. Venom. Anim. Toxins incl. Trop. Dis., 2007, 13, 1, p. 117

6 BUCARETCHI F., HERRERA SRF., HYSLOP S., BARACAT ECE., VIEIRA RJ. Snakebites by Bothrops spp in children in Campinas, São Paulo, Brazil. Rev. Inst. Med. Trop. São Paulo, 2001, 43, 329-33.

$7 \mathrm{CHO}$ W., KEZDY FJ. Chromogenic substrate and assay of phospholipase $\mathrm{A}_{2}$. Meth. Enzymol., 1991, 197, 75-9.

8 CINTRA AC., MARANGONI S., OLIVEIRA B., GIGLIO JR. Bothropstoxin-I: amino acid sequence and function. J. Protein Chem., 1993, 12, 57-64.

9 COGO JC., PRADO-FRANCESCHI J., CRUZ-HÖFLING MA., CORRADO AP., RODRIGUES-SIMIONI L. Effects of Bothrops insularis on the mouse and chick nerve-muscle preparation. Toxicon, 1993, 31, 1237-47.

10 COGO JC., PRADO-FRANCESCHI J., GIGLIO JR., CORRADO AP., CRUZHÖFLING MA., DONATO JL., LEITE GB., RODRIGUES-SIMIONI L. An unusual presynaptic action of Bothrops insularis snake venom mediated by phospholipase $\mathrm{A}_{2}$ fraction. Toxicon, 1998, 36, 1323-32.

11 DE SOUSA MV., MORHY L., ARNI RK., WARD RJ., GUTIÉRREZ JM. Amino acid sequence of a myotoxic Lys-49-phospholipase $A_{2}$ homologue from the venom of Cerrophidion (Bothrops) godmani. Biochim. Biophys. Acta, 1998, 1384, 204-8.

12 DURIGON AM., BORJA-OLIVEIRA CR., DAL BELO CA., OSHIMA-FRANCO Y., COGO JC., LAPA AJ., SOUCCAR C., RODRIGUES-SIMIONI L. Neuromuscular activity of Bothrops neuwiedi pauloensis snake venom in mouse nerve-muscle preparations. J. Venom. Anim. Toxins incl. Trop. Dis., 2005, 11, 22-33.

13 FONTES MR., SOARES AM., RODRIGUES VM., FERNANDES AC., DA SILVA RJ, GIGLIO JR. Crystallization and preliminary X-ray diffraction analysis of a myotoxic phospholipase $\mathrm{A}(2)$ homologue from Bothrops neuwiedi pauloensis venom. Biochim. Biophys. Acta, 1999, 1432, 393-5.

14 FRANCIS B., GUTIERREZ JM., LOMONTE B., KAISER II. Myotoxin II from Bothrops asper (Terciopelo) venom is a lysine-49 phospholipase $A_{2}$. Arch. Biochem. Biophys., 1991, 284, 352-9.

15 GeOghegAN P., ANGULO Y., CANGELOSI A., DIAZ M., LOMONTE B. Characterization of a basic phospholipase $A_{2}$-homologue myotoxin isolated from the venom of the snake Bothrops neuwiedii (yarara chica) from Argentina. Toxicon, 1999, 37, 1735-46. 
C. R. Borja-Oliveira et al. PURIFICATION AND N-TERMINAL SEQUENCING OF TWO PRESYNAPTIC NEUROTOXIC PLA2, NEUWIEDITOXIN-I AND NEUWIEDITOXIN-II, FROM Bothrops neuwied pauloensis (JARARACA PINTADA) VENOM. J. Venom. Anim. Toxins incl. Trop. Dis., 2007, 13, 1, p. 118

16 GINSBORG BL., WARRINER J. The isolated chick biventer cervicis nerve-muscle preparation. Brit. J. Pharmacol., 1960, 15: 410-1.

17 HALPERT J., EAKER D. Amino acid sequence of a presynaptic neurotoxin from the venom of Notechis scutatus scutatus (Australian tiger snake). J. Biol. Chem., 1975, 250, 6990-7.

18 HARVEY AL., BARFARAZ A., THOMPSON E., FAIZ A., PRESTON S., HARRIS JB. Screening of snake venoms for neurotoxic and myotoxic effects using simple in vitro preparations from rodents and chicks. Toxicon, 1994, 32, 257-65.

19 HELUANY NF., HOMSI-BRANDEBURGO MI., GIGLIO JR., PRADO-FRANCESCHI J., RODRIGUES-SIMIONI L. Effects induced by bothropstoxin, a component from Bothrops jararacussu snake venom, on mouse and chick muscle preparations. Toxicon, 1992, 30, 1203-10.

20 HOLZER M., MACKESSY SP. An aqueous endpoint assay of snake venom phospholipase $\mathrm{A}_{2}$. Toxicon, 1995, 35, 1149-55.

21 HOMSI-BRANDEBURGO MI., QUEIROZ LS., SANTO-NETO H., RODRIGUESSIMIONI L., GIGLIO JR. Fractionation of Bothrops jararacussu snake venom: partial chemical characterization and biological activity of bothropstoxin. Toxicon, $1988,26,615-27$.

22 JOHNSON EK., OWNBY CL. Isolation of a myotoxin from the venom of Agkistrodon contortrix laticinctus (broad-banded copperhead) and pathogenesis of myonecrosis induced by it in mice. Toxicon, 1993, 31, 243-55.

23 KAISER II., GUTIERREZ JM., PLUMMER D., AIRD SD., ODELL GV. The amino acid sequence of a myotoxic phospholipase from the venom of Bothrops asper. Arch. Biochem. Biophys., 1990, 278, 319-25.

24 KATZ B., MILEDI R.. The binding of acetylcholine to receptors and its removal from the synaptic cleft. J. Physiol., 1973, 231, 549-74.

25 KINI RM. Phospholipase $A_{2}-$ A complex multifunctional protein puzzle. In: KINI RM. Ed., Venom phosholipase $A_{2}$ enzymes. Structure, function and mechanism. New York: John Wiley \& Sons Inc Chichester, 1997, 1-28.

26 KONDO K., NARITA K., LEE CY. Amino acid sequences of the two polypeptide chains in beta1-bungarotoxin from the venom of Bungarus multicinctus. $J$. Biochem., 1978, 83, 101-15.

27 KONDO K., TODA H., NARITA K., LEE CY. Amino acid sequence of $\beta_{2}$-bungarotoxin from Bungarus multicinctus venom: the amino acid substitutions in the B chains. J. Biochem., 1982, 91, 1519-30. 
C. R. Borja-Oliveira et al. PURIFICATION AND N-TERMINAL SEQUENCING OF TWO PRESYNAPTIC NEUROTOXIC PLA2, NEUWIEDITOXIN-I AND NEUWIEDITOXIN-II, FROM Bothrops neuwied pauloensis (JARARACA PINTADA) VENOM. J. Venom. Anim. Toxins incl. Trop. Dis., 2007, 13, 1, p. 119

28 KONDO K., ZHANG J., XU K., KAGAMIYAMA H. Amino acid sequence of a presynaptic neurotoxin, agkistrodotoxin, from the venom of Agkistrodon halys pallas. J. Biochem., 1989, 105, 196-203.

29 KORDAS M. On the role of junctional cholinesterase in determining the time course of the end-plate current. J. Physiol., 1977, 270, 133-50.

30 LEE CY., HO CL., BOTES DP. Site of action of caudoxin, a neurotoxic phospholipase $\mathrm{A}_{2}$ from the horned puff adder (Bitis caudalis) venom. Toxicon, 1982, 20, 637-47.

31 LIND P., EAKER D. Amino-acid sequence of the alpha-subunit of taipoxin, an extremely potent presynaptic neurotoxin from the Australian snake taipan (Oxyuranus s. scutellatus). European J. Biochem., 1982, 124, 441-7.

32 MAGRO AJ., SOARES AM., GIGLIO JR., FONTES MR. Crystal structures of BnSP-7 and BnSP-6, two Lys49 phospholipases $A_{2}$ : quartenary structure and inhibition mechanism insights. Biochem. Biophys. Res. Commun., 2003, 311, 713-20.

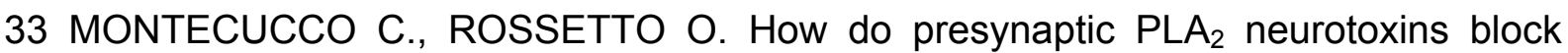
nerve terminals? Trends Biochem. Sciences, 2000, 25, 266-70.

34 OSHIMA-FRANCO Y., HYSLOP S., CINTRA AC., GIGLIO JR., DA CRUZ-HOFLING MA., RODRIGUES-SIMIONI L. Neutralizing capacity of commercial bothropic antivenom against Bothrops jararacussu venom and bothropstoxin-I. Muscle Nerve, 2000, 23, 1832-9.

35 OSHIMA-FRANCO Y., LEITE GB., SILVA GH., CARDOSO DF., HYSLOP S., GIGLIO JR., DA CRUZ-HOFLING MA., RODRIGUES-SIMIONI L. Neutralization of the pharmacological effects of bothropstoxin-I from Bothrops jararacussu (jararacuçu) venom by crotoxin antiserum and heparin. Toxicon, 2001, 39, 1477-85.

36 PEREIRA MF., NOVELLO JC., CINTRA AC., GIGLIO JR., LANDUCCI ET., OLIVEIRA B., MARANGONI S. The amino acid sequence of bothropstoxin-II, an Asp-49 myotoxin from Bothrops jararacussu (jararacuçu) venom with low phospholipase $A_{2}$ activity. J. Protein Chem., 1998, 17, 381-6.

37 RE L., BAROCCI S., CAPITANI C., VIVANI C., RICCI M., RINALDI L., PAOLUCCI G., SCARPANTONIO A., LEON-FERNANDEZ OS., MORALES MA. Effects of some natural extracts on the acetylcholine release at the mouse neuromuscular junction. Pharmacol. Res., 1999, 39, 239-45.

38 RE L., COLA V., FULGENZI G., MARINELLI F., CONCETTONI C., ROSSINI L. Postsynaptic effects of methoctramine at the mouse neuromuscular junction. Neuroscience, 1993, 57, 451-7. 
C. R. Borja-Oliveira et al. PURIFICATION AND N-TERMINAL SEQUENCING OF TWO PRESYNAPTIC NEUROTOXIC PLA2, NEUWIEDITOXIN-I AND NEUWIEDITOXIN-II, FROM Bothrops neuwied pauloensis (JARARACA PINTADA) VENOM. J. Venom. Anim. Toxins incl. Trop. Dis., 2007, 13, 1, p. 120

39 RE L., GIUSTI P., CONCETTONI C., DI SARRA B. Computerized estimation of spontaneous and evoked acetylcholine release at the neuromuscular junction. $J$. Pharmacol. Meth., 1989, 22, 233-42.

40 RE L., MORETTI V., ROSSINI L., GIUSTI P. Sodium-activated potassium current in mouse diaphragm. FEBS Lett., 1990, 270, 195-7.

41 RIBEIRO LA., ALBUQUERQUE MJ., PIRES DE CAMPOS VAF., KATZ G., TAKAOKAM NY., LEBRÃO ML., JORGE MT. Óbitos por serpentes peçonhentas no Estado de São Paulo: avaliação de 43 casos, 1988/98. Rev. Assoc. Méd. Bras., 1998, 44, 312-8.

42 RITONJA A., GUBENSEK F. Ammodytoxin A, a highly lethal phospholipase $A_{2}$ from Vipera ammodytes ammodytes venom. Biochim. Biophys. Acta, 1985, 828, 30612.

43 RODRIGUES-SIMIONI L., BORGESE N., CECCARELLI B. The effects of Bothrops jararacussu venom and its components on frog nerve-muscle preparation. Neuroscience, 1983, 10, 475-89.

44 RODRIGUES-SIMIONI L., ZAMUNER SR., COGO JC., BORJA-OLIVEIRA CR., PRADO-FRANCESCHI J., CRUZ-HOFLING MA., CORRADO AP. Pharmacological evidence for a presynaptic action of venoms from Bothrops insularis (jararaca ilhoa) and Bothrops neuwiedi (jararaca pintada). Toxicon, 2004, 43, 633-8.

45 SCHAGGER H., VON JAGOW G. Tricine-sodium dodecyl sulfate-polyacrylamide gel electrophoresis for the separation of proteins in the range from 1 to $100 \mathrm{kDa}$. Anal. Biochem., 1987, 166, 368-79.

46 SOARES AM., GUERRA-SÁ R., BORJA-OLIVEIRA CR., RODRIGUES VM., RODRIGUES-SIMIONI L., RODRIGUES V., FONTES MRM., LOMONTE B., GUTIÉRREZ JM., GIGLIO JR. Structural and functional characterization of BnSP7, a Lys49 myotoxic phospholipase $A_{2}$ homologue from Bothrops neuwiedi venom. Arch. Biochem. Biophys., 2000, 378, 201-9.

47 STÜHMER W., ROBERTS WM., ALMERS W. The loose patch clamp. In: SAKMANN B AND NEHER E, Eds. Single Channel Recording. Plenum Press, New York; 1983, 123. 
C. R. Borja-Oliveira et al. PURIFICATION AND N-TERMINAL SEQUENCING OF TWO PRESYNAPTIC NEUROTOXIC PLA2, NEUWIEDITOXIN-I AND NEUWIEDITOXIN-II, FROM Bothrops neuwied pauloensis (JARARACA PINTADA) VENOM. J. Venom. Anim. Toxins incl. Trop. Dis., 2007, 13, 1, p. 121

48 TOYAMA MH., SOARES AM., WEN-HWA L., POLIKARPOV I., GIGLIO JR., MARANGONI S. Amino acid sequence of piratoxin-II, a myotoxic lys49 phospholipase $A_{2}$ homologue from Bothrops pirajai venom. Biochimie, 2000, 82, 245-50.

49 TSAI IH., LU PJ., WANG YM., HO CL., LIAW LL. Molecular cloning and characterization of a neurotoxic phospholipase $A_{2}$ from the venom of Taiwan habu (Trimeresurus mucrosquamatus). Biochem. J., 1995, 311, 895-900.

50 VAN DEN BERGH CJ., SLOTBOOM AJ., VERHEIJ HM., DE HAAS GH. The role of aspartic acid-49 in the active site of phospholipase $A_{2}$. A site-specific mutagenesis study of porcine pancreatic phospholipase $A_{2}$ and the rationale of the enzymatic activity of Lys-49 phospholipase $\mathrm{A}_{2}$ from Agkistrodon piscivorus piscivorus venom. European J. Biochem., 1988, 176, 353-7.

51 VAN DEENEN LL., DE HAAS GH. The substrate specificity of phospholipases $A_{2}$. Biochim. Biophys. Acta, 1963, 70, 538-53.

52 VILJOEN CC., BOTES DP., KRUGER H. Isolation and amino acid sequence of caudoxin, a presynaptic acting toxic phospholipase $A_{2}$ from the venom of the horned puff adder (Bitis caudalis). Toxicon, 1982, 20, 715-37.

53 ZAMUNER SR., PRADO-FRANCESCHI J., RODRIGUES-SIMIONI L. The screening of Bothrops venoms for neurotoxic activity using the chick biventer cervicis preparation. Toxicon, 1996, 34, 314-5. 